\title{
MENINGKATKAN PRESTASI BELAJAR MATEMATIKA MENGGUNAKAN MODEL KOOPERATIF TIPE JIGSAW PADA PESERTA DIDIK SMK NEGERI 1 SAKRA
}

\author{
Sulhiah \\ SMK Neger 1 Sakra \\ sulhiahsmkn1sakra@gmail.com
}

\begin{abstract}
Cooperative learning methods of learning are not just working together, but rather on structuring. So that cooperative learning is defined as structured group learning. The purpose of writing: (a) obtaining the influence of Jigsaw type cooperative models on Mathematics learning outcomes. (b) To find out the mastery of Mathematics after the implementation of Jigsaw cooperative learning. Classroom action research (action research) is carried out in three cycles. Each cycle consists of stages namely: design, observation, reflection, and revision. The focus of this writing is students of Class XI SMK 1 East Sakra Lombok. Data obtained in the form of formative test results, observation sheets of learning activities. So it was found that the learning ability of students has increased from cycle I to cycle III namely, cycle I (66.67\%), cycle II (75.00\%), cycle III (87.50\%). The Jigsaw type cooperative model has a positive effect on the learning effect of Class XI Students of SMKN 1 Sakra East Lombok.
\end{abstract}

Keywords: Learning Mathematics, Cooperative Type Jigsaw, Vocational School

\begin{abstract}
Abstrak : Metode pembelajaran cooperative learning tidak sekedar kerja bersama, akan tetapi lebih pada penstrukturannya. Sehingga pengajaran cooperative learning definisinya sebagai belajar kelompok terstruktur. Tujuan penulisan: (a) memperoleh pengaruh model kooperatif tipe Jigsaw terhadap hasil belajar Matematika. (b) Untuk mengetahui penguasaan Matematika setelah dilaksanakannya pembelajaran kooperatif tipe Jigsaw. Penelitian tindakan kelas (action research) dilakukan dalam tiga siklus. Masing-masing siklus terdiri dari tahapan-tahapan yakni: rancangan, pengamatan, refleksi, serta revisi. Fokus penulisan ini adalah peserta didik Kelas XI SMKN 1 Sakra Lombok Timur. Data didapatkan berupa hasil tes formatif, lembar observasi kegiatan belajar. Sehingga didapatkan bahwa kemampuan belajar peserta didik mengalami peningkatan dari siklus I sampai siklus III yaitu, siklus I (66.67\%), siklus II (75.00\%), siklus III (87.50\%). Model kooperatif tipe Jigsaw berpengaruh positif terhadap pengaruh belajar Peserta didik Kelas XI SMKN 1 Sakra Lombok Timur.
\end{abstract}

Kata Kunci: Belajar Matematika, Kooperatif Tipe Jigsaw, SMK 


\section{PENDAHULUAN}

Matematika tidak hanya diperlukan untuk alat penghitung yang pasif, akan tetapi merupakan bahasa inti bagi perumusan semua teori yang melandasi semua bidang keilmuan ${ }^{1}$. Begitu pentingnya matematika sehingga di Indonesia pelajaran matematika telah diterapkan mulai dari SD sampai dengan PT. Namun dalam pelaksanaan pembelajaran matematika sebagian besar peserta didik beranggapan bahwa pelajaran matematika itu sulit dipelajari. Hal ini disebabkan oleh cara Pendidik mengajar yang tidak cocok.

Pendidik menggunakan strategi atau pendekatan pengajaran yang kurang cocok dan sukar dimengerti peserta didik, perbedaan bobot materi dan tingkat prestasi peserta didik menuntut Pendidik untuk lebih cermat dalam memilih model pembelajaran $^{2}$. Pada pembelajaran matematika peserta didik harus memiliki dasar pemahaman materi yang baik untuk mengkonstruksi pemahaman berikutnya secara berurutan. Keadaan peserta didik yang memiliki daya tangkap berbeda mengharuskan Pendidik untuk tidak memberikan perlakuan yang sama terhadap semua peserta didik.

Seiring dengan berkembangnya dunia pendidikan, muncul berbagai model pembelajaran yang memiliki kelebihan dan kekurangan masing-masing. Salah satunya adalah pembelajaran kooperatif, pembelajaran kooperatif adalah suatu pengajaran yang melibatkan peserta didik bekerja dalam kelompok-kelompok untuk menetapkan tujuan bersama ${ }^{3}$. Pembelajaran kooperatif menekankan komunikasi antar peserta didik, dimana peserta didik melaksanakan interaksi aktif bersama kawannya.

Interaksi tersebut diharapkan peserta didik bisa menguasai materi dengan baik alasannya "peserta didik akan lebih cepat memahami penjelasan dari temannya dibanding penjelasan dari pendidik disebabkan taraf pengetahuan dan pemikiran mereka lebih sejalan dan sepadan" ${ }^{4}$. Pada sebuah Penelitian terhadap pembelajaran

\footnotetext{
${ }^{1}$ Nasution, Andi Hakim, 1978,Landasan Matematika, (Jakarta : Bhatara Karya Aksara.1978) hlm. 17 1998) hlm.

${ }^{2}$ Hasibuan. J.J. dan Moerdjiono. Proses Belajar Mengajar. Bandung: Remaja Rosdakarya.

${ }^{3}$ Ali, Muhammad. Pendidik Dalam Proses Belajar Mengajar. (Bandung: Sinar Baru Algesindon.1996) hlm. 2 hlm. 75

${ }^{4}$ Djamarah, Syaiful Bahri. 2002.Strategi Belajar Mengajar. Jakarta: Rineksa Cipta 2001)
} 
kooperatif menampilkan bahwa pebelajaran kooperatif memiliki andil yang amat positif terhadap peserta didik yang rendah hasil belajarnya ${ }^{5}$.

Dari uraian tersebut di atas, jelas bahwa pembelajaran kooperatif bermanfaat meningkatkan kemampuan belajar siswa pada semua tingkatan baik peserta didik yang daya tangkapnya tinggi maupun rendah. Berdasarkan hal tersebut maka penulis ingin mencoba melaksanakan penelitian dengan judul "Meningkatkan Prestasi Belajar Matematika Melalui Pembelajaran Kooperatif Tipe Jigsaw Pada Peserta didik Kelas XI SMK Negeri 1 Sakra"

\section{METODE}

Penelitian ini tindakan (action research). juga termasuk penelitian deskriptif, karena menggambarkan suatu teknik pembelajaran diterapkan dan bagaimana hasil yang diinginkan sehingga tercapai ${ }^{6}$. Tindakan kelas menggunakan Pendidik sebagai peneliti, penanggung jawab penuh. Kehadiran peneliti sebagai Pendidik di kelas sebagai pengajar tetap dan dilakukan seperti biasa, sehingga peserta didik tidak tahu kalau diteliti. Dengan cara ini diharapkan didapatkan data yang seobjektif mungkin demi kevalidan data yang diperlukan.

\section{HASIL DAN PEMBAHASAN}

\section{SIKLUS I}

\section{Tahap Perencanaan}

Tahap ini penulis mempersiapkan perangkat pembelajaran yang terdiri dari rencana pelajaran 1 , LKS 1 , soal tes formatif 1 dan alat-alat pengajaran yang mendukung.

\section{Tahap Kegiatan dan Pelaksanaan}

Pelaksanaan proses belajar pada siklus I dilaksanakan tanggal 14 Maret 2018 di Kelas XI dengan jumlah 24 peserta didik. Peneliti bertindak sebagai pendidik. Belajar mengajar mengacu pada rencana pelajaran yang sudah dipersiapkan. observasi dilakukan serentak dengan pelaksaaan belajar sehingga akhir proses belajarr peserta

\footnotetext{
${ }^{5}$ Nur, Moh..Pemotivasian Siswa untuk Belajar. Surabaya. University Press. Universitas Negeri urabaya 2001)hlm: 2.

${ }^{6}$ Arikunto, S. Dasar-Dasar Evaluasi Pendidikan. (Jakarta: Bumi Aksara. 2001) hlm.20
} 
didik diberi tes formatif I agar tujuannya mengetahui tingkat keberhasilan peserta didik dalam kaitannya dengan belajarr yang sudah dilaksanakan. Hasil penelitian siklus I :

Tabel 4.2. Rekapitulasi Hasil Tes Formatif Siswa Pada Siklus I

\begin{tabular}{|c|l|c|}
\hline No & \multicolumn{1}{|c|}{ Uraian } & Hasil Siklus I \\
\hline 1 & Nilai rata-rata tes formatif & 68,75 \\
2 & Jumlah siswa yang tuntas belajar & 16 \\
3 & Persentase ketuntasan belajar & 66,67 \\
\hline
\end{tabular}

Tabel di atas dapat dijelaskan menerapkan pembelajaran kooperatif tipe jigsaw di peroleh nilai rata-rata prestasi belajar peserta didik sebesar 68,75 dan ketuntasan belajar mencapai 66,67\% atau ada 16 peserta didik yang tuntas belajar dari 24 peserta didik. Hasil itu menunjukkan pada siklus pertama secara klasikal peserta didik belum tuntas belajar, karena peserta didik yang memperoleh nilai $\geq 65$ hanya sebesar 66,67\% lebih kecil dari persentase ketuntasan yang diinginkan sebesar 85\%. Disebabkan oleh peserta didik masih baru dan asing terhadap metode baru yang diterapkan dalam proses belajar mengajar.

\section{Refleksi}

Kegiatan belajar mengajar diperoleh hasil pengamatan antara lain :

1. Pendidik kurang baik dalam memotivasi peserta didik demikian pula dalam menyampaikan tujuan pembelajaran.

2. Pendidik kurang tepat dalam pengelolaan waktu.

3. Peserta didik kurang begitu antusias selama pembelajaran berlangsung.

\section{Revisi}

Pada siklus I ini masih banyak kekurangan, sehingga perlu diperlukan revisi untuk dilakukan pada siklus selanjutnya.

1. Pendidik terampil memotivasi peserta didik dan lebih jelas dalam menyampaikan tujuan pembelajaran, dimana peserta didik diajak terlibat langsung setiap kegiatan yang dilakukan;

2. Pendidik perlu mendistribusikan waktu yang baik dengan menambahkan informasi-informasi yang dirasa penting dan member setiap catatan; 
3. Pendidik harus lebih bersemangat dalam memotivasi peserta didik sehingga peserta didik lebih antusias lagi.

\section{SIKLUS II}

\section{Tahap Perencanaan}

Tahap ini peneliti mempersiapkan perangkat pembelajaran yang terdiri dari rencana pelajaran dua, soal tes formatif du dan alat-alat pengajaran yang mendukung.

\section{Tahap Kegiatan dan Pelaksanaan}

Pelaksanaan kegiatan belajar mengajar untuk siklus II dilaksanakan pada tanggal 26 Maret 2018 di Kelas XI SMKN1 Sakra Lombok Timur dengan jumlah peserta didik 24 peserta didik, peneliti bertindak sebagai Pendidik.

Proses belajar mengajar mengacu pada rencana pelajaran dengan memperhatikan revisi pada siklus I, kekurangan pada siklus I tidak terulang lagi pada siklus II. observasi mengajar, dilaksanakan bersamaan dengan pelaksanaan belajar pada akhir proses belajar mengajar peserta didik diberi tes formatif II dengan tujuan dalam mengetahui tingkat keberhasilan peserta didik dalam belajar mengajar yang telah dilakukan. Instrument yang digunakan adalah tes formatif II. Data hasil penelitian pada siklus II adalah sebagai berikut.

Tabel 4.3. Hasil Tes Formatif Siswa Pada Siklus II

\begin{tabular}{|c|l|c|}
\hline No & \multicolumn{1}{|c|}{ Uraian } & Hasil Siklus II \\
\hline 1 & Nilai rata-rata tes formatif & 72,08 \\
2 & Jumlah siswa yang tuntas belajar & 18 \\
3 & Persentase ketuntasan belajar & 75,00 \\
\hline
\end{tabular}

Dari tabel di atas diperoleh nilai rata-rata prestasi belajar peserta didik yakni 72,08 dengan ketuntasan belajar mencapai 75,00 \% atau ada 18 peserta didik dari 24 peserta didik sudah tuntas belajar. Hasil ini menunjukkan bahwa pada siklus II ini ketuntasan belajar secara klasikal telah mengalami peningkatan sedikit lebih baik dari siklus I. Adanya peningkatan hasil belajar peserta didik ini karena peserta didik membantu peserta didik yang kurang mampu dalam mata pelajaran yang mereka pelajari. Disamping itu adanya kemampuan Pendidik yang mulai meningkat dalam proseS belajar mengajar. 


\section{Refleksi}

Dalam pelaksanaan kegiatan belajar diperoleh informasi dari hasil pengamatan antara lain : (1) Memotivasi peserta didik; (2) Membimbing peserta didik merumuskan kesimpulan/menemukan konsep; (3) Pengelolaan waktu.

\section{Revisi Rancangan Pelaksanaan}

Kegiatan belajar pada siklus II ini masih terdapat kekurangan-kekurangan. Maka perlu adanya revisi untuk dilaksanakan pada siklus II antara lain:

1. Pendidik dalam memotivasi peserta didik hendaknya dapat membuat peserta didik lebih termotivasi selama proses belajar mengajar berlangsung.

2. Pendidik harus lebih dekat dengan peserta didik sehingga tidak ada perasaan takut dalam diri peserta didik baik untuk mengemukakan pendapat dalam kelompoknya atau bertanya.

3. Pendidik harus lebih sabar dalam membimbing peserta didik merumuskan kesimpulan/menemukan konsep.

4. Pendidik harus mendistribusikan waktu secara baik sehingga kegiatan pembelajaran dapat berjalan sesuai dengan yang diharapkan.

5. Pendidik menambahkn lebih banyak contoh soal serta memberi soal-soal latihan pada peserta didik buat dikerjakan setiap kegiatan belajar mengajar.

\section{SIKLUS III}

\section{Tahap Perencanaan}

Tahap ini penulis menyiapkan perangkat pembelajaran yang terdiri: rencana pelajaran tiga, soal tes formatif tiga dan alat-alat pengajaran yang mendukung.

\section{Tahap Kegiatan dan Pengamatan}

Pelaksanaan kegiatan belajar mengajar untuk siklus III Dilaksanakan pada tanggal 28 Maret 2018 di Kelas XI SMKN 1 Sakra Lombok Timur, dengan jumlah peserta didik 24 peserta didik. Peneliti bertindak sebagai Pendidik.

Proses belajar mengajar berpedoman pada rencana pelajaran dengan mencermati revisi pada siklus II, sehingga kesalahan serta kekurangan pada siklus II tidak terulang lagi pada siklus III. Pengamatan dilakukan bersamaan dengan pelaksanaan belajar mengajar. Sehingga pada akhir proses belajar mengajar peserta didik di beri tes formatif III dengan tujuan agar mengetahui tingkat keberhasilan 
peserta didik sebagai proses belajar mengajar yang telah dilakukan. Instrumen yang dipakai adalah tes formatif III. Data hasil penelitian pada siklus III adalah :

Tabel 4.4. Hasil Tes Formatif Siswa Pada Siklus III

\begin{tabular}{|c|l|c|}
\hline No & \multicolumn{1}{|c|}{ Uraian } & Hasil Siklus III \\
\hline 1 & Nilai rata-rata tes formatif & $\mathbf{7 7 , 0 8}$ \\
2 & Jumlah siswa yang tuntas belajar & $\mathbf{2 1}$ \\
3 & Persentase ketuntasan belajar & $\mathbf{8 7 . 5 0}$ \\
\hline
\end{tabular}

Berdasarkan tabel di atas diperoleh nilai rata-rata tes formatif sebesar 77,08 dan dari 24 peserta didik yang telah tuntas sebanyak 21 peserta didik dan 3 peserta didik belum mencapai ketuntasan belajar. Maka secara klasikal ketuntasan belajar telah tercapai sebesar 87,50 \% (termasuk kategori tuntas).

Hasil pada siklus III ini mengalami peningkatan lebih baik dari siklus II. Adanya peningkatan hasil belajar pada siklus III ini dipengaruhi oleh adanya peningkatan kemampuan peserta didik dalam mempelajari materi pelajaran yang telah diterapkan selama ini serta tumbuhnya rasa tanggung jawab kelompok dari peserta didik yang lebih mampu untuk mengajari kawannya kurang mampu.

\section{Refleksi}

Tahap ini akan dikaji apa terlaksana dengan baik maupun yang masih kurang baik dalam proses belajar mengajar dengan pembelajaran kooperatif tipe jigsaw.

Data yang telah diperoleh dapat diuraikan antara lain :

1. Dalam proses belajar mengajar pendidik sudah melakukan keseluruhan pembelajaran dengan cukup baik. Walaupun ada beberapa aspek masih ada belum sempurna, akan tetapi persentase pelaksanaannya untuk tiap-tiap aspek cukup besar.

2. Data hasil observasi diketahui ada peserta didik aktif selama proses belajar berlangsung.

3. Kekurangan pada siklus sebelumnya sudah mengalami perbaikan dan peningkatan sehingga menjadi lebih baik.

4. Hasil belajar siswa pada siklus III mencapai ketuntasan. 


\section{Revisi}

Pelaksanaan Pada siklus III Pendidik telah menerapkan pembelajaran kooperatif tipe jigsaw dengan baik, dilihat dari aktivitas peserta didik serta hasil belajar peserta didik pelaksanaan proses belajar mengajar sudah berjalan dengan baik.Tidak lagi diperlukan revisi terlalu banyak, tetapi yang perlu diperhatikan untuk tindakan selanjutnya yakni memaksimalkan dan mempertahankan apa yang sudah terbentuk (kerjasama kelompok) dengan tujuan agar pada pelaksanaan proses belajar mengajar selanjutnya, penerapan pembelajaran kooperatif tipe jigsaw dapat meningkatkan proses belajar mengajar sehingga tujuan pembelajaran dapat tercapai.

\section{PEMBAHASAN}

\section{Ketuntasan Hasil Belajar Peserta Didik}

Melalui hasil peneilitian ini menunjukkan bahwa pembelajaran kooperatif tipe jigsaw memiliki dampak positif dalam meningkatkan prestasi belajar peserta didik. Semakin mantapnya pemahaman dan penguasaan peserta didik terhadap materi yang telah disampaikan pendidik selama ini (ketuntasan belajar meningkat dari sklus I, II, dan III) yaitu masing-masing 66,67\%, 75,00\%, dan 87,50\%. Pada siklus III ketuntasan belajar peserta didik secara klasikal telah tercapai.

\section{Kemampuan Pendidik dalam Mengelola Pembelajaran}

Berdasarkan analisis data, diperoleh aktivitas peserta didik dalam pembelajaran kooperatif tipe jigsaw dalam setiap siklus mengalami peningkatan. Hal ini berdampak positif terhadap peningkatan prestasi belajar peserta didik dan penguasaan materi pelajaran yang telah diterima selama ini, yakni bisa ditunjukkan dengan meningkatnya nilai rata-rata peserta didik pada setiap siklus yang terus mengalami peningkatan.

\section{Aktivitas Pendidik dan Peserta Didik}

Berdasarkan analisis data, diperoleh aktivitas peserta didik dalam proses pembelajaran Matematika dengan pembelajaran kooperatif tipe jigsaw yang paling dominan adalah, mendengarkan/memperhatikan penjelasan Pendidik, dan diskusi antar peserta didik dimana peserta didik yang lebig pandai mengajari peserta didik yang kurang pandai dalam kelompoknya. Jadi dapat dikatakan bahwa aktivitas peserta didik dapat dikategorikan aktif. 
Sedangkan untuk aktivitas Pendidik selama pembelajaran telah melaksanakan langkah-langkah pembelajaran kooperatif tipe jigsaw dengan baik. Hal ini terlihat dari aktivitas Pendidik yang muncul di antaranya aktivitas membimbing dan mengamati peserta didik dalam melaksanakan kegiatan, menjelaskan materi yang tidak dimengerti peserta didik, memberi umpan balik/evaluasi/tanya jawab dimana prosentase untuk aktivitas di atas cukup besar.

\section{KESIMPULAN}

1. Kooperatif tipe jigsaw memiliki dampak positif dapat meningkatkan prestasi belajar peserta didik pada matematika yang ditandai peningkatan ketuntasan belajar peserta didik setiap siklus, yakni siklus I (66,67\%), siklus II (75,00\%), siklus III $(87,50 \%)$.

2. Penerapan pembelajaran kooperatif tipe jigsaw mempunyai pengaruh positif, yaitu dapat meningkatkan motivasi belajar peserta didik dalam pembelajaran Matematika, hal ini ditunjukan dengan antusias peserta didik yang menyatakan bahwa peserta didik tertarik dan berminat dengan pembelajaran kooperatif tipe jigsaw sehingga mereka menjadi termotivasi untuk belajar.

3. Pembelajaran kooperatif tipe jigsaw memiliki dampak positif terhadap kerjasama antara peserta didik, hal ini ditunjukkan adanya tanggung jawab dalam kelompok dimana peserta didik yang lebih mampu mengajari temannya yang kurang mampu.

\section{DAFTAR PUSTAKA}

Ali, Muhammad. 1996.Pendidik Dalam Proses Belajar Mengajar. Bandung: Sinar Baru Algesindon.

Arikunto, Suharsimi. 2001.Dasar-Dasar Evaluasi Pendidikan. Jakarta: Bumi Aksara. Djamarah, Syaiful Bahri. 2002.Strategi Belajar Mengajar. Jakarta: Rineksa Cipta.

Hasibuan. J.J. dan Moerdjiono. 1998.Proses Belajar Mengajar. Bandung: Remaja Rosdakarya.

Nasution, Andi Hakim, 1978,Landasan Matematika, Jakarta : Bhatara Karya Aksara.

Nur, Moh. 2001.Pemotivasian Siswa untuk Belajar. Surabaya. University Press. Universitas Negeri Surabaya 